\title{
DĚJINY MEDICÍNY JAKO DĚJINY VĚDY A VZDĚLANOSTI
}

\author{
PETR SVOBODNÝ
}

\section{HISTORY OF MEDICINE AS A HISTORY OF SCIENCE AND EDUCATION}

Using as his chief example the interdisciplinary area of history of medicine, the author presents various intersections and links common in current, up-to-date approaches to the history of education. Various functions of university clinics as subjects of interest to the historians of medicine of the Modern Era (eighteenth to twentieth century) can serve as a model of research in a number of areas. These include the history of education (clinical internships), history of science (clinical research), history of healthcare and social care (their therapeutic functions), history of professions (physicians, scientists, teachers), and the social role of scholars. In this way, the subject encompasses most areas belonging to a broadly conceived history of education.

Keywords: medicine - education - science - teaching - therapeutic function - clinic - scholars - social history

DOI: $10.14712 / 23365730.2019 .8$

Interdisciplinární obor dějiny medicíny ${ }^{1}$ je i v Česku pevně institucionalizován ${ }^{2}$ např́íklad ústavem na 1. lékařské fakultě Univerzity Karlovy, výrazným podílem na práci Společnosti pro dějiny věd a techniky a jejího časopisu nebo pravidelnými česko-slovenskými sympózii s mezinárodní účastí. ${ }^{3}$ Donedávna však stál stranou hlavních proudů české historiografie; tento trend se ovšem v poslední době mění a témata a přístupy novějších oblastí dějin medicíny se stále častěji stávají předmětem zájmu mainstreamových institucí (např́klad historických ústavů filozofických fakult v Praze, Pardubicích nebo Českých Budějovicích nebo ústavů AV ČR) i jednání sjezdů českých historiků. ${ }^{4}$

„Tradični'“ dějiny medicíny 5 (pěstované často samotnými lékaři) byly doménou událostních dějin, sledujících neustálý ,„pokrok“ reprezentovaný velkými osobnostmi a jejich

1 Tato studie vznikla jako součást řešení programu Progres Q23 Dějiny univerzitní vědy a vzdělanosti.

2 Základní vymezení tematického pole dějin medicíny, jeho institucionální zajištění (ústavy, společnosti, časopisy) a některé nejvýznamnější publikace v evropském kontextu posledního čtvrtstoletí najde zájemce in: Petr SvobodnÝ, Dějiny mediciny na přelomu tisíciletí, Český časopis historický 101/4, 2003, s. 916-927; TÝž, Déjiny mediciny (převážně) v Německu na počátku 21. století, AUC-HUCP 56/1, 2016, s. 217-223. Dějiny a stav oboru v českých zemích představil Karel ČERNÝ, History of medicine in the Czech Republic: Past and Present, History of Medicine (Russian Journal for the History of Medicine and Allied Sciences) 3/2, 2016, s. 185-198.

3 Zatím poslední (11.) se uskutečnilo roku 2011 v Ústí nad Labem: <http://dvt.hyperlink.cz/akce/msdmfvm11-abstrakty.pdf> (poslední př́istup 21. 11. 2018).

4 Nejvýrazněji např́klad na 10. sjezdu v Ostravě v roce 2015:<http://konference.osu.cz/sjezd2011ostrava/dok/ volne/program-dejiny_tela.pdf> (poslední př́stup 21.11.2018); př́spěvky ze sekce byly publikovány: Milena Lenderová - Vladan HAnulí - Daniela Tinková (eds.), Déjiny těla: prameny, koncepty, historiografie, Červený Kostelec 2013.

5 Vymezení a vývoj „klasických“ i novějších dějin medicíny: Wolfgang U. ECKART - Robert JüTTE, Medizingeschichte. Eine Einführung, Köln - Weimar - Wien 2007; Mark JACKSON, The Oxford Handbook of the History of Medicine, Oxford 2011. 
úspěchy, obvykle bez užších vazeb na širší kontexty. Ty se staly rozhodujícími nejprve pro sociální a posléze kulturní dějiny medicíny, ${ }^{6}$ podobně jako v př́ibuzných oborech dějin vědy (respektive vědění, idejí nebo intelektuálních dějin) a dějin školství (respektive vzdělávání nebo vzdělanosti). Nejnovějším př́nosem pro dějiny medicíny v nejširším vymezení jsou príistupy historickoantropologické (včetně dějin pacientů, dějin těla, kulturních dějin smrti apod.), ${ }^{7}$ gender studies ${ }^{8}$ nebo třeba disabled studies. ${ }^{9}$

Metaforou zrození moderní medicíny jako vědy i umění léčit je fenomén kliniky, tedy místa výuky nových profesionálů, výzkumu a špičkové zdravotní péče organizované státem na přelomu 18. a 19. století. Jednou z ikon (nejen) moderních dějin medicíny je Michel Foucault, zejména jeho kniha Zrození kliniky a koncept biomoci. ${ }^{10}$ Dějiny kliniky ve středoevropském pojetí (tedy jako instituce sdílené jak univerzitou, tak nemocnicí) jsou ideálním objektem, na kterém lze demonstrovat podstatnou část témat a metod současných dějin medicíny 18. až 20. století jako oboru zkoumaného jak dějinami školství (a vzdělanosti), dějinami vědy (a vědění), tak tou částí sociálních dějiny, které se zabývají profesními skupinami a zdravotními a sociálními systémy.

Tři funkční roviny klinik (výuková, výzkumná, léčebná), tedy tři témata dějin medicíny jako modelového prríkladu dějin vzdělanosti představím v následujícím expozé převážně na př́kladu recentních výstupů českých historiček a historiků medicíny i bez př́vlastků zhruba posledního čtvrtstoletí. ${ }^{11}$ Jsou mezi nimi publikace jak tradičnějšího typu (monografie, kapitoly v monografiích nebo články k dějinám lékařských fakult a velkých fakultních nemocnic, ale též dalších léčebných ústavů), tak publikace nejnovější, vycházející právě z aktuálních teoretických a metodologických podnětů (především zmíněné gender studies, koncept biomoci, dějiny těla atd).

Před závorku je třeba vytknout, že pojem klinika je nadále použiván ve dvojím smyslu: 1. v užším, tedy jako oddělení nemocnice sloužící klinické výuce mediků (případně dalších kategorií zdravotního personálu, např́íklad porodních asistentek nebo sester), analogicky $\mathrm{k}$ tomu jsou předmětem zájmu historiků medicíny pochopitelně i univerzitní teoretické ústavy a další zařízení (laboratoře, ambulance, poradny atd.) a naopak mimouniverzitní léčebné ústavy sloužící současně výchově nebo výzkumu; 2. v metaforickém slova smyslu,

6 Keir Waddington, An Introduction to the Social History of Medicine. Europe since 1500, Basingstoke - New York 2011; Frank Huisman - John H. Warner (edd.), Locating Medical History. The Stories and Their Meanings, Baltimore - London 2004.

7 Daniela TinkovÁ, Biomoc a „politická anatomie lidského a společenského těla“. Foucaultưv koncept „, biomoci "ve vztahu $k$ otázce modernizace státu, zrození humanitnich věd a medikalizace společnosti na přelomu 18. a 19. století, in: Lucie Storchová (ed.), Conditio humana - konstanta či historická proměnná? Koncepty historické antropologie a teoretická reflexe v současné historiografii, Praha 2007, s. 115-137; Milena LenDEROVÁ - Daniela TinKová - Vladan Hanulí, Tělo mezi medicínou a disciplínou. Promény lékařského obrazu a ideálu lidského těla a tělesnosti v dlouhém 19. století, Praha 2014; Daniela Tinkové, Tělo, véda a stát. Zrození porodnice v osvicenské Evropě, Praha 2010.

8 Lucie Storchová, Gender, in: Lucie Storchová a kol., Koncepty a dějiny. Proměny pojmů v současné historické vědě, Praha 2014, s. 194-204.

9 Kateřina KolÁŘová (ed.), Jinakost, postiženi, kritika. Společenské konstrukty nezpůsobilosti a hendikepu. Antologie textů z oboru disability studies, Praha 2012. Dějiny medicíny jako průsečík různých novějších metodologických konceptů definoval stručně též Václav GruBHOFfer, Nemoc, terapie a umírání v medicině konce raného novověku: proměny konceptů mezi barokem a prvni polovinou 19. století, Dějiny věd a techniky 50/1, 2017, s. 28-46.

10 Michel Foucault, Zrození kliniky, Červený Kostelec 2010 (francouzský originál 1963).

11 Citované práce jsou jenom vrcholkem ledovce, nejvýznamnější či nejtypičtější práce, vybrané jako ilustrace představovaných směrů, $\mathrm{v}$ žádném př́padě nejde o pokus podat výběrovou, natožpak úplnou bibliografii. 
tj. jako společné označení pro kliniky, ústavy a další zařízení nebo ještě obecněji pro „dílny vědy a vzdělanosti“.

\section{Klinika jako místo výuky: dějiny vzdělávání, vzdělání, školství}

Univerzitní výchova lékařu patř́ tradičně $\mathrm{k}$ základním tématům dějin jak medicíny, tak vysokého školství. Středověké a raně novověké studium medicíny se ovšem výrazně lišilo od moderního, mimo jiné jen rudimentární přítomností „klinické“ výuky u lůžka nemocného na jedné straně a výsledkem této výuky, tedy formováním kompetentního léčitele a jeho postavením a funkcemi v rovněž rudimentárních „zdravotnických systémech“, na straně druhé. Teprve s rozvojem kliniky jako místa praktické výuky u lůžka nemocného (a analogicky u pitevního nebo laboratorního stolu) získává činnost klinických pracovišt' lékařských fakult onen synergický charakter efektivní výchovy, moderní vědy i účinné léčby. Vyučující, špičkoví reprezentanti svých vědeckých disciplín, zde předávají své znalosti nováčkům v profesi a na vrcholné úrovni léčí své pacienty. ${ }^{12}$ Rozkvět klinik v 19. století $\mathrm{v}$ tomto vymezení, alespoň ve středoevropském prostoru, časově koreluje s formulací a prosazováním humboldtovského ideálu jednoty vědy a výuky. ${ }^{13}$

Součástí výukového provozu na lékařských fakultách bylo od „zrození kliniky“ rovněž postgraduální vzdělávání, v 19. a první polovině 20. století odlišné od praxe na jiných fakultách. Absolventský titul doktora medicíny neodpovídal doktorským titulům získávaným na základě disertací na ostatních fakultách. Na klinikách a ústavech lékařských fakult se po jeho získání dále vzdělávalo značné procento absolventů formou asistentur, které byly ve své krátkodobé podobě především přípravou na profesní zkoušky nutné k získání titulu odborného lékaře, delší asistentury pak formou prvního stupně vědecké kariéry (pokračující obvykle titulem docenta, případně profesora). I po změnách v oblasti postgraduální výchovy ve druhé polovině 20 . století (tzv. kandidatury věd od 50. do počátku 90 . let, poté doktorské studium) si kliniky uchovaly své významné místo v postgraduální vědecké výchově (v oblasti medicíny ovšem paralelně se specializační př́ípravou na tzv. atestace jak na klinikách, tak v resortních doškolovacích ústavech). ${ }^{14}$

\section{Klinika jako místo vědy a výzkumu: dějiny vědy, vědění, idejí}

$\mathrm{S}$ vědeckou výchovou na klinikách se tak dostáváme nejen $\mathrm{k}$ druhému pilíri jejich činnosti, pěstování vědy, ale současně též ke třetímu, tj. k vytváření a uplatnění specifického typu profesionála v oblasti medicíny, at' již specializovaného praktického lékaře nebo lékaře-vědce. Typ vysoce kvalifikovaného lékaře vyučujícího a bádajícího na univerzitní klinice,

12 Pro lékařské fakulty pražských univerzit od středověku po 20. století viz př́slušné kapitoly in: František KAVKA - Josef Petráñ (eds.), Dějiny Univerzity Karlovy 1347/48-1990, I-IV, Praha 1995-1998. Podobným typem souhrnných institucionálních dějin univerzitní teoretické i klinické medicíny jsou např́iklad: Ulrich von HeHL Uwe JoHn - Manfred Rudersdorf (Hgg.), Geschichte der Universität Leipzig 1409-2009, IV, Fakultäten, Institute, zentrale Einrichtungen, Leipzig 2009, lékařská fakulta zde na s. 951-1046.

13 Proměny humboldtovského ideálu v praxi 19. a 20. století: Karel ŠIMA - Petr PABIAN, Ztracený Humboldtův ráj. Ideologie jednoty výzkumu a výuky ve vysokém školství, Praha 2013.

14 Ivana Svobodová (ed.), 50 let postgraduálního vzdèlávání ve zdravotnictví. Jubilejní sborník, Praha, s. d. [2003]. 
obvykle též angažujícího se ve veřejném prostoru, ${ }^{15}$ mimochodem dokonale odpovídá obrazu ideální profese, jak jej dlouhodobě formulují žebříčky popularity povolání, ve kterých se na prvních tř̌ech místech v různém pořadí umist uje vysokoškolský učitel - vědec - lékař (spolu se zdravotní sestrou). ${ }^{16}$

Role klinik (a ústavů, laboratoří atd.) jako špičkových pracovišst' lékařské vědy, opět především ve středoevropském prostoru a do poloviny 20 . století téměř výhradně, poté s významnými konkurenty v podobě akademických a resortních výzkumných ústavi̊, je v české historiografii medicíny i obecněji v dějinách vědy reflektována velmi často. Vedle souhrnných publikací zde máme především klasické dějiny institucionální, oborové nebo biografie, obvykle v tradičním internalistickém diskursu stabilního pokroku reprezentovaného „velkými muži““ ${ }^{17}$ Některé z nich se ovšem ve větší či menší míře věnují i širším společenským, kulturním, ekonomickým nebo politickým kontextům dějin vědy (vědění, idejí). ${ }^{18}$

\section{Klinika jako specializovaný léčebný ústav: sociální dějiny vzdělanců (intelektuálů), profesí, institucí, systémů}

Univerzitní kliniky v rámci velkých nemocnic (v hlavních nebo krajských městech) jsou jako špičková pracoviště pevnou součástí dobově podmíněných nemocničních sítí a celkově zdravotnických systémů. ${ }^{19}$ Nejlepší lékaři zde vykonávají svou základní profesi (a vedle ní zmíněné činnosti výukové a badatelské). Mají tedy (pochopitelně s dalšími institucemi) své významné místo jak v procesu profesionalizace, tedy vytváření specializované a vysoce kvalifikované profese lékaře, tak funkci jednoho z nejprestižnějších míst výkonu povolání. ${ }^{20}$ Vytváření a výkon profese lékařů v 19. a 20. století je stabilní součástí bádání o moderních elitách a vzdělaneckých profesích, mj. v rámci konceptu tzv. Bildungsbürgertum (rozvíjeného např́ílad bielefeldskou školou sociálních dějin), ${ }^{21}$ další vývoj profese

15 Ideálním typem spojujícím v nejvyšší možné rovině tři funkce klinického lékaře, navíc veřejného intelektuála a politika druhé poloviny 19. století, podrobně popsala: Helena KoKEŠovÁ, Eduard Albert (1841-1900). Český intelektuál ve Vidni, Praha 2014.

$16<$ https://cs.wikipedia.org/wiki/Presti\%C5\%BE_povol\%C3\%A1n\%C3\%AD> (poslední př́stup 21. 11. 2018).

17 Jako jeden z nejnovějších př́ikladů velmi rozsáhlé produkce tohoto typu je možné uvést publikaci: Jan ŠvÁB, Kapitoly z dějin chirurgie v českých zemích, Praha 2016.

18 Teoretické ukotvení dějin vědy (respektive vědění) najde historik (nejen) medicíny mj. v těchto novějších pracích: Daniel Špelda, Proměny historiografie védy, Praha 2009; Marco Stella, Tvorové vědy. Živé modely a budování védeckých komunit (disertační práce FHS UK), Praha 2014, dostupná na $<$ https://is.cuni.cz /webapps/zzp> (poslední př́istup 21. 11. 2018); Lucie StorchovÁ - Jiř́i RưžIČKA, Věda/vědění, in: L. Storchová, Koncepty a dějiny, s. 269-280. Dějiny idejí/intelektuální dějiny stručně představil V. GruBHoffer, Nemoc, terapie a umírání, s. 29.

19 Petr Svobodný - Ludmila Hlaváč́ová, Dějiny lékařství v českých zemich, Praha 2004; Eva KŘižovÁ, Zdravotnické systémy v mezinárodním srovnání, Praha 1998.

20 Ludmila HlaváčKová - Petr Svobodný - Jan BŘízA, Dějiny V̌̌eobecné fakultní nemocnice v Praze 1790-2010 (3. rozšířené vydání), Praha 2011; Johanna Bleker - Volker Hess (Hgg.), Die Charité. Geschichte(n) eines Krankenhauses, Berlin 2010.

21 Charle McClelland - Stephan Merl - Hannes Siegrist (Hg.), Professionen in modernen Osteuropa / Professions in Moder Eastern Europe, Giessen 1995; Petr Svobodný - Jan Havránex (edd.), Profesionalizace akademických povolání věeských zemích v 19. a prvni polovině 20. století, Praha 1996. V obou kolektivních monografiích o profesionalizaci jsou př́slušné pasáže věnovány i lékařum (v cizojazyčné vedle českých také mad’arským a ruským). Perspektivní směr bádání reprezentují př́ípadové a modelové studie jednotlivých profesí v 18. až 20. století, včetně lékařu a vědců (i veřejně činných), představené v kolektivních monografiích: Jiří Malíř et al., Člověk na Moravě ve druhé polovině 18. století, Brno 2009; Lukáš Fasora et al., Člověk 
na přelomu 20. a 21. století je předmětem zájmu sociologů medicíny. ${ }^{22}$ Kliniky byly, zvláště v 18. a 19. století, ovšem i místem vzdělávání, respektive kontroly nad výkonem praxe dalších zdravotnických profesí (ranlékařo̊, chirurgů, lékárníků, babiček) a také v této oblasti se o nich proto v nedávné době objevily studie v rámci výzkumů formování a vzestupu tzv. drobné inteligence v období osvícenství a národního obrození. ${ }^{23}$

Funkce klinik a jejich personálu na jedné a pacientů na druhé straně je v poslední době také stále více kontextualizována z pohledu dějin pacientů, ${ }^{24}$ dějin těla a gender studies. ${ }^{25}$ Stručně řečeno: různá těla, resp. gendery vyžadují různé zacházení ze strany lékařů (např. obory gynekologie a pediatrie), případně poskytují jiné možnosti profesního uplatnění ve zdravotnictví (modelově lékař/muž versus ošetřovatelka/žena). ${ }^{26}$ Rozhodující role moderních klinik (respektive ústavů, konkrétně patologickoanatomických) je předmětem bádání také v oblasti medikalizace smrti, počínaje osvícenstvím. ${ }^{27}$

\section{Klinika v sociálních a politických sítích: společenské role vzdělanců}

Klinická (a stejně tak i teoretická) výuka medicíny od konce 18. století zároveň výrazně vstupuje do společenských a politických struktur, v nichž se instituce a jejich představitelé výrazně podílejí nejenom na formulaci politik v rámci vlastních kompetencí (zdravotních, sociálních, školských, vědeckých), ale aktivně či pasivně se dostávají také do osidel vysoké politiky. Zrození kliniky v 18. století i tzv. „,velké uvěznění“ pacientů (například psychiatrických) je v obecné historiografii zahraniční a stále více i české výsostným polem, kde se úspěšně uplatňují koncepty medikalizace, profesionalizace a biomoci. ${ }^{28}$ Medikalizace řady problémů (například v oblasti lidské reprodukce či psychických odchylek a postižení), tedy vedle jiných aspektů také jejich zvědečtění zásluhou vzdělaných profesionálů, znamenala jejich přesun z oblasti náboženství nebo práva právě mezi předměty zkoumání dějin vzdělanosti a vědy. ${ }^{29}$ Podobná těsná souvislost je patrná také v oblasti péče o smyslově nebo

na Moravě 19. století, Brno 2004; Lukáš FASORA et al., Člověk na Moravě v první polovině 20. století, Brno 2006. Kvalifikovanými zdravotnickými profesemi se zabývá v rámci výzkumu inteligence Andrea PoKLUDOvÁ, Formování inteligence na Moravě a ve Slezsku 1857-1910, Ostrava 2008, s. 79-139; metodika a stav výzkumu v české historiografii tamtéž, s. 12-26.

22 Eva KŘížová, Proměny lékařské profese z pohledu sociologa, Praha 2006.

23 Tématem drobné inteligence, včetně zdravotnických profesí, se zabývala mj. konference Osvícenství-to jsme my. Formování a vzestup drobné inteligence v 18. stoleti konaná v záŕí 2015 v Praze. K jednotlivým zdravotnickým profesím například D. Tinková, Tělo, věda, stát; Alžběta LaŇová, Vývoj chirurgické profese od obdobi raného novověku do roku 1848 na území Prahy, Documenta Pragensia (v tisku).

24 Vladan Hanulí, Dějiny těla z pohledu Patientengeschichte, in: M. Lenderová - V. Hanulík - D. Tinková, Dějiny těla, s. $179-227$.

25 M. Lenderová - D. Tinková - V. Hanulíx, Tělo mezi medicínou a disciplínou, kapitoly IV. a VI.

26 Petr Svobodný, Lékařky v českých zemích v první polovině 20. století, AUC-HUCP 35/1-2, 1995, s. 75-87; Ulrike Lindner - Merith Niehuss (Hgg.), Ärztinnen - Patientinnen. Frauen in deutschen und britischen Gesundheitswesen des 20. Jahrhunderts, Köln - Weimar - Wien 2002.

27 Václav Grubhoffer, Zdánlivá smrt. Noční můra osvícenské Evropy, Polička - Praha 2018; TÝž, Pod závojem smrti. Poslední věci Schwarzenbergů v letech 1732-1914, České Budějovice 2013.

28 Daniela Tinková, Zákeřná Mefitis. Zdravotní policie, osvěta a veřejná hygiena v pozdně osvícenských Čechách, Praha 2012.

29 S konceptem medikalizace v poslední době nejdůsledněji pracují: Daniela TinkovÁ, Hř́ch, zločin, šilenstvi v čase odkouzlováni světa, Praha 2004; TÁž, Tělo, věda, stát; V. Grubhoffer, Pod závojem smrti; TÝž, Zdánlivá smrt. 
tělesně postižené (dnes „osoby s jinými potřebami“) a jejich vzdělávání. Specializované ústavy od 19. do poloviny 20. století jim poskytovaly nejen základní potřeby a vzdělání, ale zpravidla v úzké návaznosti na př́ílušné kliniky (oční, ušní, chirurgické, ortopedické) i specializovanou zdravotní péči. ${ }^{30}$

Posledním př́íkladem z oblasti dějin medicíny je podíl lékařu (a mezi nimi zvláště klinických nebo teoretických univerzitních pracovišt') na excesech totalitních režimů 20. století (např́klad sterilizace, eutanázie nebo rasové výzkumy prováděné na univerzitních klinikách 3. řrišs ${ }^{31}$ nebo disciplinační role psychiatrických nemocnic v Sovětském svazu), obecněji tedy otázka zodpovědnosti nebo selhání vzdělanců (intelektuálů). $\mathrm{V}$ obou uvedených prípadech lze př́slušné problémy studovat (a v Německu už se tak explicitně děje) jako extrémní prípady biomoci. ${ }^{32}$

\section{Jaké tedy z této „klinické studie“ vyplývají závěry pro dějiny vzdělanosti?}

Když jsem byl vyzván $\mathrm{k}$ vypracování shrnujícího referátu pro sjezdovou sekci, nenašel jsem žádnou vyhovující definici dějin vzdělanosti. ${ }^{33}$ Pokusil jsem se proto o vymezení předmětu dějin vzdělanosti s pomocí mně nejlépe známých dějin medicíny. Výsledkem bohužel není úplná definice, ale jen několik poznámek.

Samo slovo vzdělanost a s ním spojené výrazy (včetně adjektiv) objímají široké sémantické pole a jednotlivé termíny je nutné rozlišovat. V základní rovině se vzdělaností (nebo vzděláním) obvykle rozumí individuální vlastnost jako souhrn znalostí a dovedností získaných (nejen) v procesu vzdělávání a schopnost uplatnit je v profesním životě.

Podstatnější pro naše téma je vyšší rovina - kolektivní. Do sféry vzdělanosti je tak třeba zařadit souhrn (systém) institucí a osob zajišttujících proces vzdělávání (tedy vzdělávaci instituce v užším smyslu, jinými slovy školy) a zprostředkujících nebo uchovávajících jeho výsledky (osvětové instituce nebo knihovny). Stejně tak sem patř́ souhrn teorií, metod a postupů získávání znalostí (věda a výzkum) a předávání znalostí (výuka). Výsledkem těchto procesů je vzdělání, tj. korpus získaných poznatků, metod a teorií jako předpoklad jejich uplatňování ve vzdělaných (nejen vysokoškolsky) profesích. Produktem i spolutvưrcem procesu vzdělávání, zde př́edevším vysokoškolského, jsou vzdělanci ${ }^{34}$ (v horším př́i-

30 Petr Svobodný, Tři generace rodiny Aloise Klara - tři fáze péče o nevidomé v Čechách, in: Zdeněk Hojda Marta Ottlová - Roman Prahl (ed.), Útisk - charita - vyloučení. Sociální 19. století, Praha 2015, s. 170-189.

31 V českém prostředí je tento směr reprezentován především publikacemi Michala Šimůnka a jeho spolupracovníků, např́klad: Michal ŠIMŮNeK - Dietmar Schulze (Hg.), Die nationalsozialistische „Euthanasie“ im Reichsgau Sudetenland und Protektorat Böhmen und Mähren 1939-1945, Červený Kostelec 2008. Specifickým žánrem dějin medicíny jsou odedávna „nemoci mocných“, v kontextu dějin medicíny v období totalitních režimů dovedených k dokonalosti, viz Milan NovÁK - Michal V. ŠIMŮNEK, Zdraví nemocní řišští protektoři v Čechách a na Moravě 1939-1945, Praha 2018.

32 Koncept biomoci v rámci studia dějin medicíny v období nacionálního socialismu je explicitně aplikován in: Wolfgang U. ECKART, Medizin in der NS-Diktatur, Wien - Köln - Weimar 2012.

33 Představit dějiny vzdělanosti jako specifickou oblast historického bádání se pokusili: Michal SvAToš - Antonín Kostlán, Dějiny vzdělanosti v českých zemích, in: Jiří Pešek - Ota Konrád (edd.), VIII. sjezd českých historiků, Praha 2000, s. 215-219.

34 Termín vzdělanci nebo učenci je obvykle používán pro období raného novověku a přechodu k době moderní (přelom 18. a 19. století), zatímco pro další historická období (ale nejen pro ně) je obvyklejší synonymum (nikoliv úplné) intelektuálové (viz následující poznámka). Ke „vzdělancům“ staršího typu např́íklad: Alena MíšKOvÁ - Martin FrANC - Antoním KostLÁn (ed.), Bohemia docta. K historickým kořenům vědy v českých zemích, Praha 2010; Josef Förster - Ondřej PODÁvKA - Martin Svatoš (ed.), Historia litteraria v českých zemích od 17. do počátku 19. století, Praha 2015. 
padě nedovzdělanci), v různých specifických kontextech a rolích označovaní jako profesionálové, inteligence, intelektuálové, s prívlastky i bez nich. ${ }^{35}$

To vše tedy, na př́kladu jednoho z výrazných témat tradičních i současných dějin medicíny, kterým je fenomén kliniky, patř́ dle mého mínění do sféry dějin vzdělanosti.

\section{PETR SVOBODNÝ}

\section{Die Geschichte der Medizin als Wissenschafts- und Bildungsgeschichte}

\section{ZUSAMMENFASSUNG}

Am Beispiel des interdisziplinären Faches Medizingeschichte stellt Verfasser Durchdringungen bzw. Zusammenhänge dar, welche in der modern konzipierten Disziplin der Bildungsgeschichte üblich sind, und unternimmt somit den Versuch, einen Diskussionsbeitrag zur Definition und Bestimmung der Bildungsgeschichte zu leisten (gegenüber dem älteren und engeren Konzept der Geschichte des Schulwesens). Als Modellbeispiel dient ihm die Geschichte der Universitätskliniken vom Ende des 18. Jahrhunderts bis heute. Anhand der jüngsten historiografischen Arbeiten (überwiegend) tschechischer Historiker und Historikerinnen, die nicht nur die Medizingeschichte in ihren ursprünglichen Grenzen, sondern auch verschiedene Richtungen der Sozial- und Kulturgeschichte repräsentieren, verfolgt er folgende Forschungssegmente: 1. Geschichte der Kliniken als Lehranstalten, also im Kontext der Geschichte des Schulwesens (in diesem Falle konkret des medizinischen Hochschulwesens, und zwar sowohl des prä- als auch des postgradualen). 2. Geschichte der Kliniken als hochrangige (bis Mitte des 20. Jahrhunderts praktisch das Monopol innehabende) Zentren biomedizinischer Forschung, also im Kontext der Wissenschaftsgeschichte (wissenschaftlicher Einrichtungen, wissenschaftlicher Disziplinen) bzw. der Wissens- und Ideengeschichte. 3. Geschichte der Kliniken als hochspezialisierte Heilanstalten, einschließlich der Sozialgeschichte Gebildeter (Intellektueller) einerseits und in medizinischen Berufen, Einrichtungen und Systemen Ausgebildeter andererseits. 4. Geschichte der Kliniken und ihrer Angestellten in sozialen und politischen Netzwerken, einschließlich der gesellschaftlichen Rolle Gebildeter. Auf allen Untersuchungsebenen der Geschichte der Kliniken in den vergangenen ungefähr drei Jahrzehnten sind soziale und kulturelle Kontexte deutlich sichtbar, also ein wesentlicher Charakterzug einer breit konzipierten Bildungsgeschichte des 18. bis 20. Jahrhunderts.

Deutsche Übersetzung Wolf B. Oerter

Petr Svobodný

Ústav dějin a archiv Univerzity Karlovy

petr.svobodny@ruk.cuni.cz

35 Christophe CharLe, Intelektuálové v Evropě 19. století, Praha 2004; Petr HLAváčEK (ed.), Intelektuál ve veřejném prostoru. Vzdělanost, společnost, politika, Praha 2012. 